\title{
Mathematical Determination of the Cultural Interaction between Medieval Groups
}

\author{
Mehmet Erbudak ${ }^{1}$ \\ ${ }^{1}$ Laboratorium für Festkörperphysik, ETHZ, CH-8093 Zurich and, Physics Department, Boğaziçi University, TR-Istanbul
}

\author{
Article Info \\ Keywords: Correlation, Medieval ar- \\ chitecture, Ornaments, Symmetry, Tes- \\ sellation, Wallpaper groups \\ 2010 AMS: 20H15, 62H20, 82D25. \\ Received: 26 January 2020 \\ Accepted: 5 June 2020 \\ Available online: 31 August 2020
}

\begin{abstract}
A mathematical classification of two-dimensional ornaments into 17 plane symmetry groups is presented, which were created by five medieval cultural groups of Middle East. The data are considered representative for the cultural groups. By applying a correlation algorithm on the individual use of symmetry classes by each cultural group, the strength of the interaction between the pairs of groups are quantitatively determined. The analysis shows that the strongest similarity in the creation of periodic ornaments is between Rum Seljuks and Arab Muslims and between Armenians and Byzantium. It is also found that the Rum Seljuks, followed by Armenians, are the most interactive cultures. This report is the first attempt to quantify cultural communication by mathematical means.
\end{abstract}

\section{Introduction}

It seems justified to claim that the region of the Middle East, the so-called fertile crescent, is the cradle of our civilizations [1]. Evidence to support this claim is constantly being discovered. I find that there is a region of cultural exchange somewhere north of the fertile crescent where prominent cultures have interacted. Here I present arguments to substantiate this claim qualitatively and quantitatively.

The symmetry properties of planar ornaments are characteristic of an ethnic group that produced them [2]. We classify the ornaments according to their symmetries using group theoretical methods of mathematics. In analogy to surface crystallography, this results in 17 symmetry groups [3]. To reach our goal, we consider artistic ornaments of five individual cultural groups that lived in and around the geographical region of interest.

The comparison of the ornamental features of two groups shows the degree of their cultural similarity or even cultural interaction. To qualitatively determine the interaction, I apply a correlation algorithm to each pair of symmetry distributions, and I obtain a similarity function for the degree of interaction between two groups under consideration. I apply the procedure to all pairs of groups. This operation is the new idea of the present work to rigorously evaluate cultural similarities.

The first cultural establishment one encounters in this region is Armenia, which extends from modern Armenia to the Van Lake plateau in the south and further southwest to Cappadocia and Cilicia [4]. There are four other groups of people who come and go to the region of cultural exchange after the year 700 AD.

I mention the Eastern Roman Empire [5], later called Byzantium [6]. Emperor Constantine declared Constantinople the capital of his empire after his victory at Milan. The Eastern Roman Empire expanded to the East, conquered Anatolia, today's Syria and its bordering territories. The Byzantine capital is home to at least two masterpieces, the Hagia Sofia and the Chora Church. The Adriatic coast of Croatia and Italy were already in the possession of the Empire. Inspired by Christianity, Byzantium created other breathtaking examples of its culture: the Basilica of San Marco in Venice, the Church of San Vitale in Ravenna, the Cathedral and Monreale Monastery near Palermo, to name but a few. The map in Figure 1 shows schematically the Byzantine territories with their capital (encircled) at the intersection of Europe and Asia. After the emergence of Islam around 620, the peoples of the Arabian peninsula reached their military and cultural peak during the Umayyad and Abbasid dynasties, followers of the Muslim prophet. They first moved north and northeast to spread their confession by asserting their language and culture [7].

The Great Seljuks are Turkic tribes from the prairies of Central Asia who settled in Iran, especially in Khorasan and later in the southern regions of the Caspian Sea $[8,9,10]$. On their way west they met Byzantine powers to defeat them once and for all. After their own 
dissolution due to lack of leadership, their descendants founded a culturally high-ranking sultanate, the Seljuks of Anatolia or the Rum Seljuks [11, 12]. In Turkish usage Rum stands for Romans or simply West. The Seljuks are responsible for the spread of the Turkish language in Western Iran, the Caucasus, Iraq, Syria, Anatolia, etc.

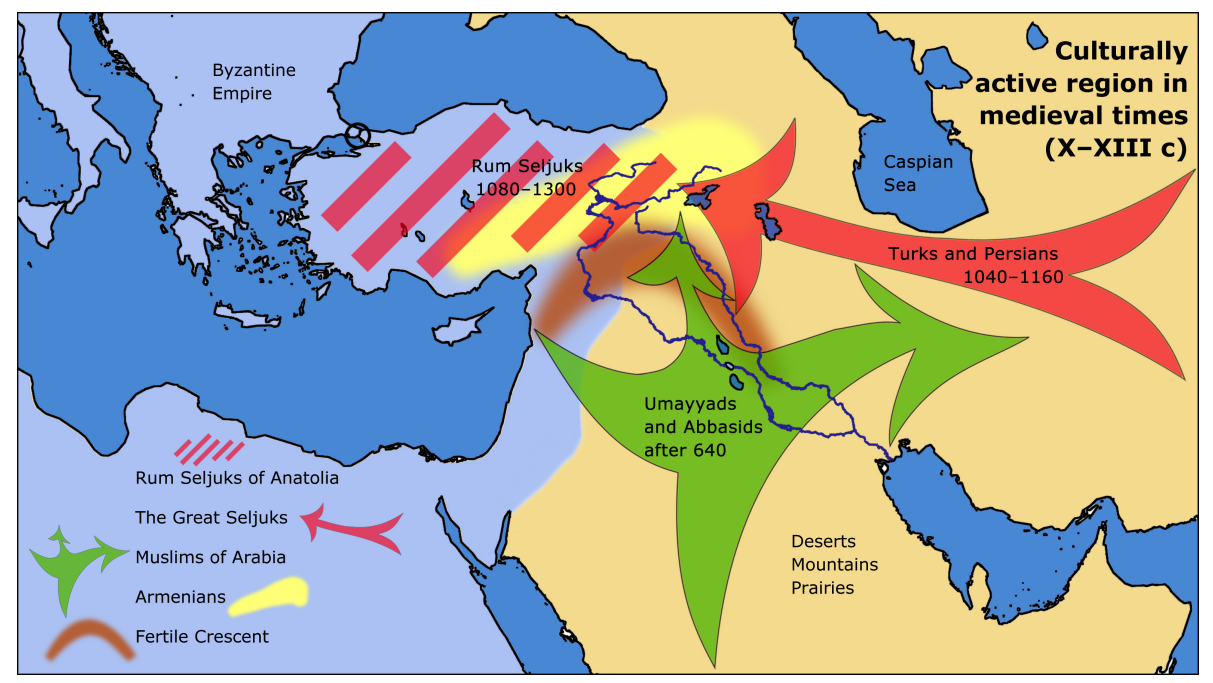

Figure 1: The Middle East, the Balkans and Italy, including parts of Arabia, during the greatest expansion of the Byzantine Empire (light blue) in the 10th to 13the centuries. The circle marks their capital Constantinople. The only stationary civilization is that of the Armenians. Byzantium shrinks under the influence of the Turkish-Persian Seljuk Empire, which moves west. Muslims from Arabia advance north and northeast in their missionary expansion.

It is like a historical play. We have the cast, the stage and the program from about the tenth to the end of the thirteenth century. Below are some details about the cast and their artistic achievements, before I go into the cultural interactions. These cultural groups overlapped geographically and in time, or at least were neighbors. Therefore they influenced each other in their artistic habits.

In analogy to surface crystallography, we classify the ornaments according to their symmetries using group-theoretical methods of mathematics. We obtain 17 symmetry groups [3]. I apply this method to artistic ornaments of five individual cultural groups living in the geographical region under investigation. I record the occurrence of each symmetry group for these five cultures and visually evaluate the similarities and differences.

The comparison of the ornamental features of two groups shows the degree of cultural similarity and possibly their cultural interaction. To determine the degree of interaction, I apply a correlation algorithm to each pair of symmetry distributions, which yields a similarity function. I apply this procedure to all pairs of groups.

The classification of the ornament symmetries into 17 crystallographic groups is not a new achievement. Nevertheless, it is objective, rigorous and easily repeatable, anywhere and at any time. The new achievement of this work consists of the idea and the method of how I compare the results of the classification and obtain a similarity function for the correlation of each pair of cultural groups. Since I have five different groups when I consider the interaction of each group with its four neighbors, I end up with ten correlation functions. This is a mathematical procedure that is applied to the established classification scheme for the first time and allows a quantitative measurement of mutual interactions. I find that cultural groups that interacted most with its neighbors were the Rum Seljuks and Armenians, while the Great Seljuks developed their works of art quite independently.

\section{Mathematical classification of ornaments}

The creation of two-dimensional ornaments in art and architecture is an artistic achievement. The ornament is a two-dimensional surface decoration that covers the surface completely and periodically. For a given ornament, I first determine the unit cell, the smallest surface that is periodically repeated in two dimensions to form a lattice. The translation operation to cover the entire surface is consistent with the symmetry properties of the unit cell. I then study the rotational symmetries. A given shape is either two-, three-, four- or sixfold symmetric $(n=2,3,4,6)$ or has no such rotational property $(n=1)$. These numbers refer to the fraction of a complete circle around which an object is rotated to be mapped onto itself. After determining the rotational symmetries, I look for reflection symmetries in two main directions. Again, a mirror symmetrical object is imaged onto itself when it is reflected at a mirror symmetry line. A glide symmetry can practically be compared to foot steps left on sand on both sides of the glide reflection line. This scheme is the basis of the plane symmetry group, a formalism which is exactly the same as that we use to describe the atomic order on a crystal surface [13].

The formalism of crystal groups was proposed at the end of the 19th century, when mathematicians used crystallography to study the symmetry problem and found that, according to group theory, there are 17 different types of periodic distribution of atoms on a surface. These crystal groups are exactly the same as those I obtain for a culturally created artistic ornament. This assumption was made by George Pólya in 1924 [14] and is proved by Edith Müller in her dissertation which examines the ornaments of the Alhambra Palace in Granada, Spain [15]. Since then, there have been several fundamental papers on this subject [3], mainly based on the results of Müller.

The 17 distinct translational planar patterns can be characterized according to the convention of crystallographers and physicists [3]. The ornamental patterns are also called the wallpaper group. The designation of each group follows a four-digit recipe: The first letter is a $p$ or a $c$, primitive or centered depending on the type of lattice. The letter $c$ is used if there is an additional unit in the centre of the cell. The second digit is the rotational order $n$. The third and fourth digits are a mirror reflection $m$ or glide reflection $g$ along the two major directions. If there is no mirror or glide, we write 1. 


\section{Results}

I have classified two-dimensional periodic ornaments created by five medieval societies, the Byzantine Empire, the Armenians, the Muslims of Arabia, the Great Seljuks and the Rum Seljuks. The results of this classification are presented below in graphic form.

\subsection{Byzantium}

Byzantium has created numerous architectural monuments with a generous collection of ornaments. They belonged to the Eastern Orthodox Nomination and founded churches wherever the Empire ruled. Nevertheless, I could not find a statistical relevant number of ornaments in their main church Hagia Sofia nor in Chora and San Vitale. Therefore, I concentrated on the floor ornaments of the Basilica San Marco in Venice [16]. On the marble floor of the basilica there are at least 730 different individual areas, which are decorated with periodically arranged marbles. The frequency of the plane groups is shown in Figure 2. In my analysis I found that almost $80 \%$ of the ornaments have a fourfold symmetry. Interestingly there are no ornaments with threefold symmetry.

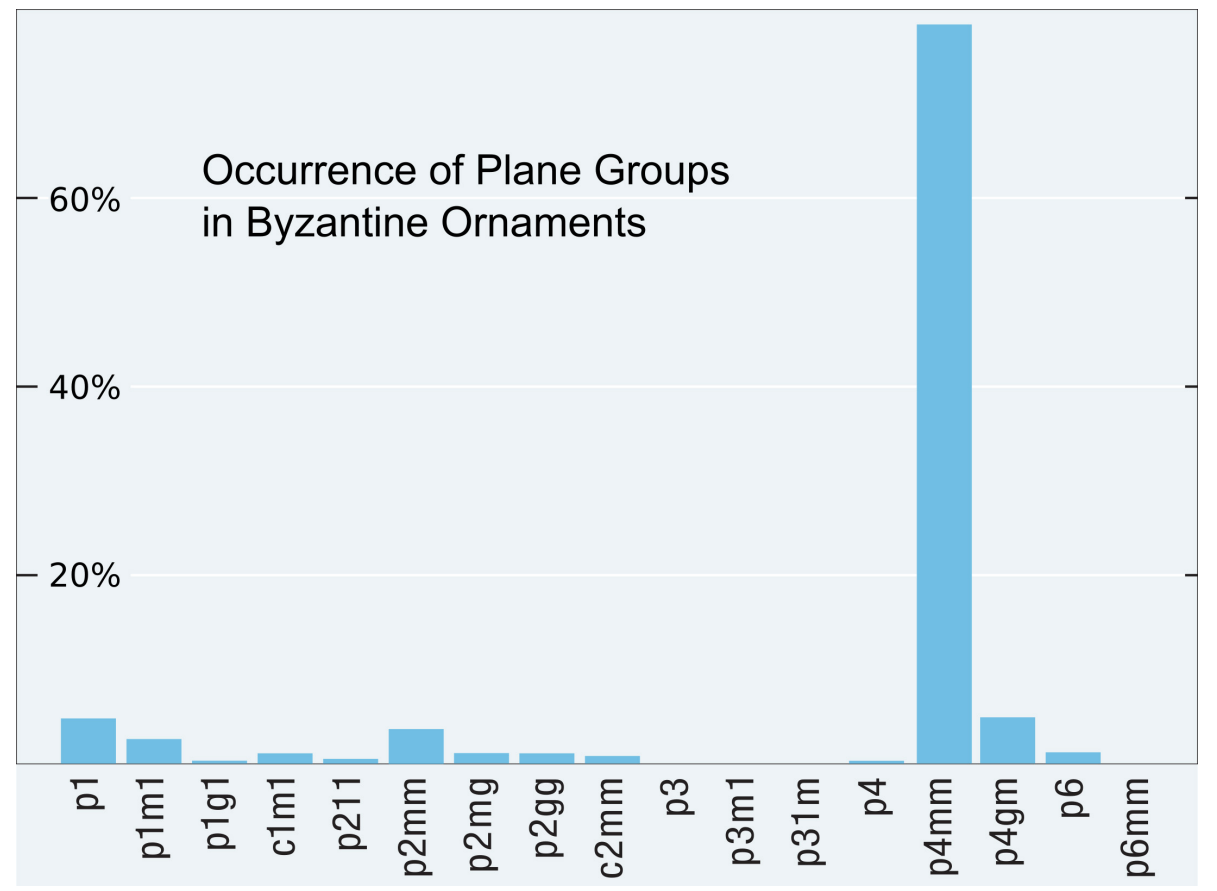

Figure 2: The frequency of the symmetry group in the floor ornaments of the 10th century built St. Marc's Cathedral in Venice. The results are based on 730 individual ornaments and come from Ref. [16].

Byzantium did not last long. In 1071 a battle against Alparslan of the Great Seljuks took place in Manzikert near Lake Van, which initiated the collapse of the Eastern Roman Empire until they lost their capital to the Ottomans in 1453.

\subsection{Armenia}

In the Middle Ages Armenia was mainly ruled by nobles. Two important families were the Bagratuni in the north and the Artsrunik in the south, from which Vaspurakan emerged as the most powerful kingdom in Armenia. It has suffered from Islamic and Byzantine aggressions and constant civil wars. But the mighty Gagik I was recognized by the Arabs and Byzantium as the King of Armenia and proved that their interactions were not always hostile. Armenians were even appointed Byzantine emperors and were occasionally married to Arabs. The traditional Bagratuni capital Duin was destroyed by a devastating earthquake in 893. Trdat was the brilliant architect who built Ani, the next capital. Trdat was even invited by the Byzantine Emperor Basil II to rebuild the dome of Hagia Sofia after it was also destroyed by another devastating earthquake in 989 [4].

The Armenians confess to Oriental Orthodoxy. They have created numerous churches with stone carvings on the walls and khachkars, gravestones. We have recently studied Armenian ornaments and classified them [17]. Apart from the fourfold symmetry found in the majority, the Armenian ornaments have a balanced distribution. Figure 3 displays the results.

\subsection{Muslims of Arabia}

The next group of people I consider are the Muslims from the Arabian Peninsula, Egypt and Syria after they converted to Islam in 622. Around 680, the Umayyad and Abbasid dynasties moved north to the Armenian countries and east to the Iranian territories. In Iran they met the Persian, Turkish and Mongolian peoples and converted them to Islam. They also brought their cultures and together with the new Muslims they created several buildings such as mosques, minarets and madrasas. I found examples of the cultural habits that originated from Syria and Egypt and were brought by the Arab-Muslim occupation [19]. Arab warriors also moved west along the North African coast in the early Umayyad period and established a great culture on the Iberian peninsula. The Umayyads of Andalusia lasted more than eight centuries and shaped the European civilization. 


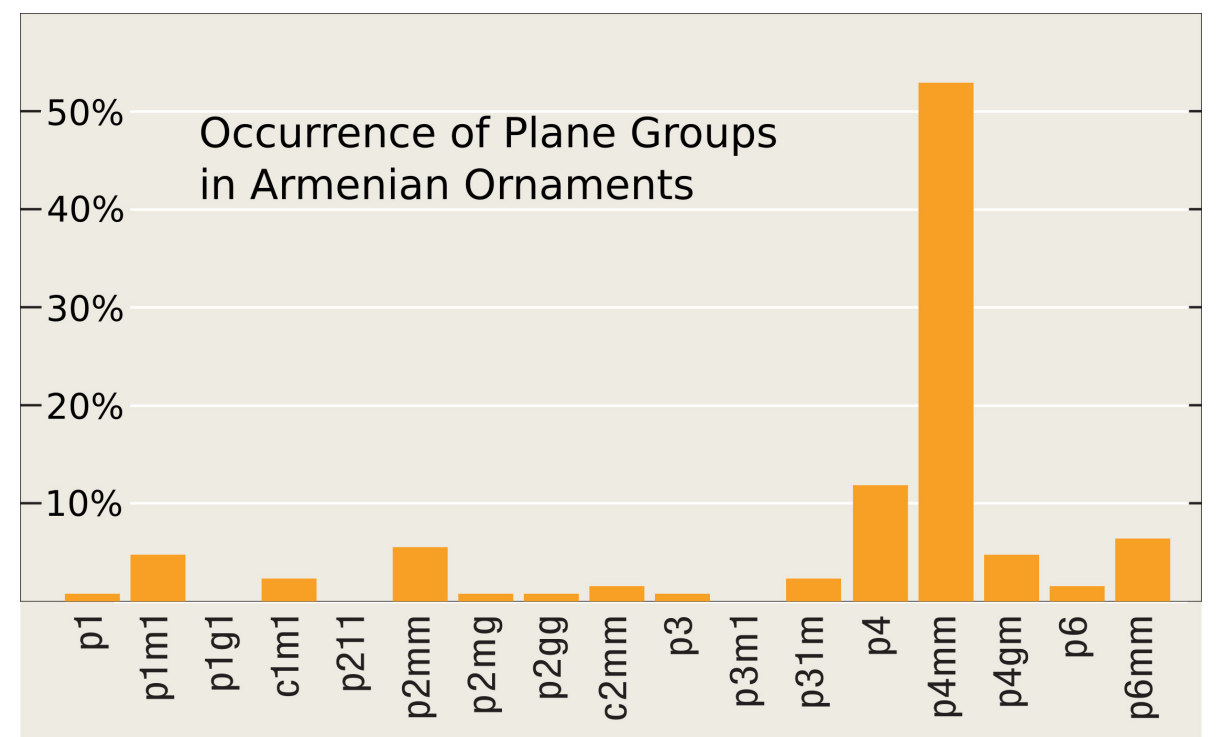

Figure 3: The plane groups of Armenian ornaments from the personal collection of Armen Kyurkchyan [18]. The results are based on 123 individual ornaments.

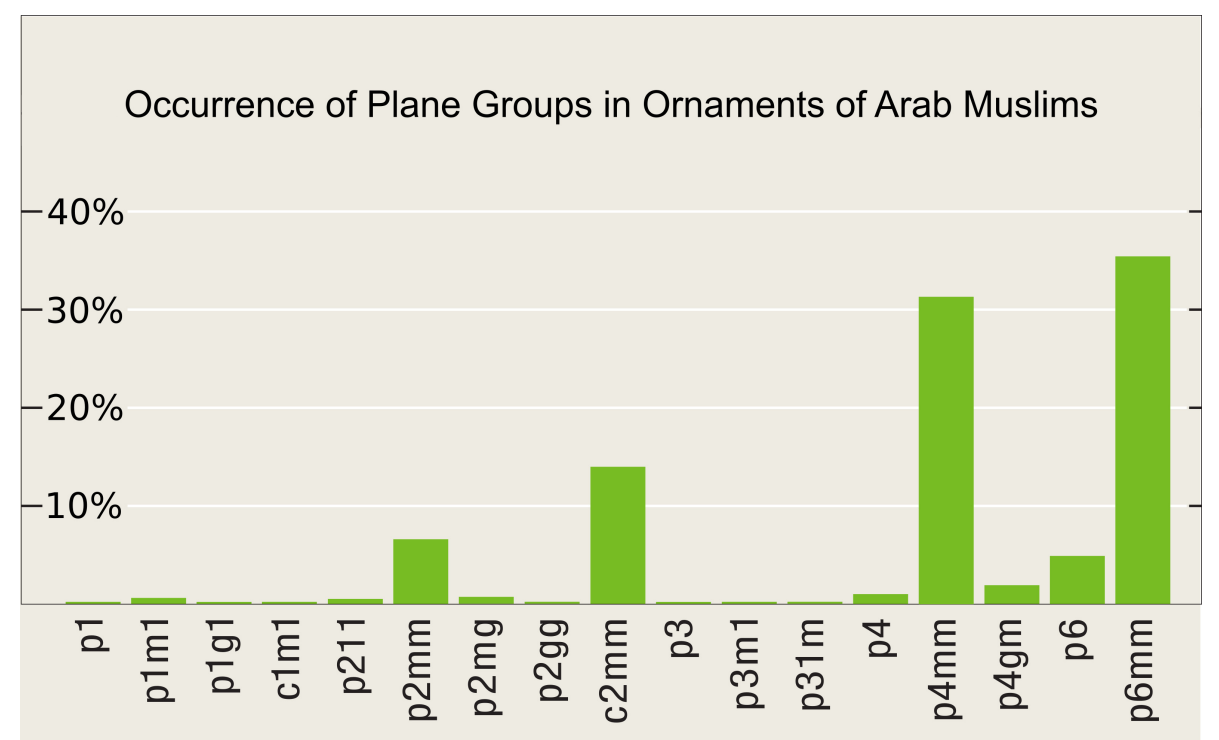

Figure 4: Arab-Muslim ornaments from Syria and Egypt [19, 20]. For the classification 200 drawings are used.

Bourgoin published drawings of more than 200 Arab-Muslim ornaments without mathematical classification [19]. Later in the 1970s two groups, Emil and Milota Makovicky and Syed Jan Abas and Amer Shaker Salman, studied these ornaments according to the group-theoretical recipe [20]. Here I use the average of their results to compensate for smaller differences and show them in Figure 4.

\subsection{The Great Seljuks}

Another culture that has left its mark in this geography are the Great Seljuks. They are Turkish nomad shepherds from the prairies of Central Asia, descendants of the Göktürk tribes. Since the 8th century they spread steadily westward to the Aral Sea and fought against the invading Islamic Arabs until their tribal leader Seljuk Bey took over Islam about 960. His sons first moved from Khorasan to Afghanistan around 1030 and then further west. They conquered Shiraz in 1050 before occupying all of Iran and Baghdad, the seat of the Abbasid caliphs. As Sunni muslims, they fought against the Shiite Fatimids of Cairo. Still as nomads, after 1060 they carried out campaigns with Christians on the borders of the empire in Anatolia and the Caucasus to plunder the territories. Finally, in 1071, Alpaslan ravaged Byzantium in Manzikert and captured Emperor Romanus Diogenes. One year later Alpaslan moved to the east to his residence in Isfahan.

After the assassination of Alpaslan in 1072, fratricidal wars between his descendants in 1150 broke the empire apart into a complete anarchy. The Great Seljuk Empire was a composition of Turks, who were the best fighters, and the Persians, who were administratively the best organizers. It is difficult to distinguish clearly between the Persians and Seljuks in their artistic achievements. They are certainly strongly influenced by Islam, as they built mosques and huge minarets in addition to the madrasas. I have collected the ornamental material from various sources $[7,9,21,22]$. An earlier analysis was limited to about 30 ornaments from the photographic collection of Emil Makovicky [21]. The results of plane groups shown in Figure 5 contain additional 55 ornaments. The high value of the $c 2 \mathrm{~mm}$ group is a result of the brick-laying technique used by Seljuks on minarets. 


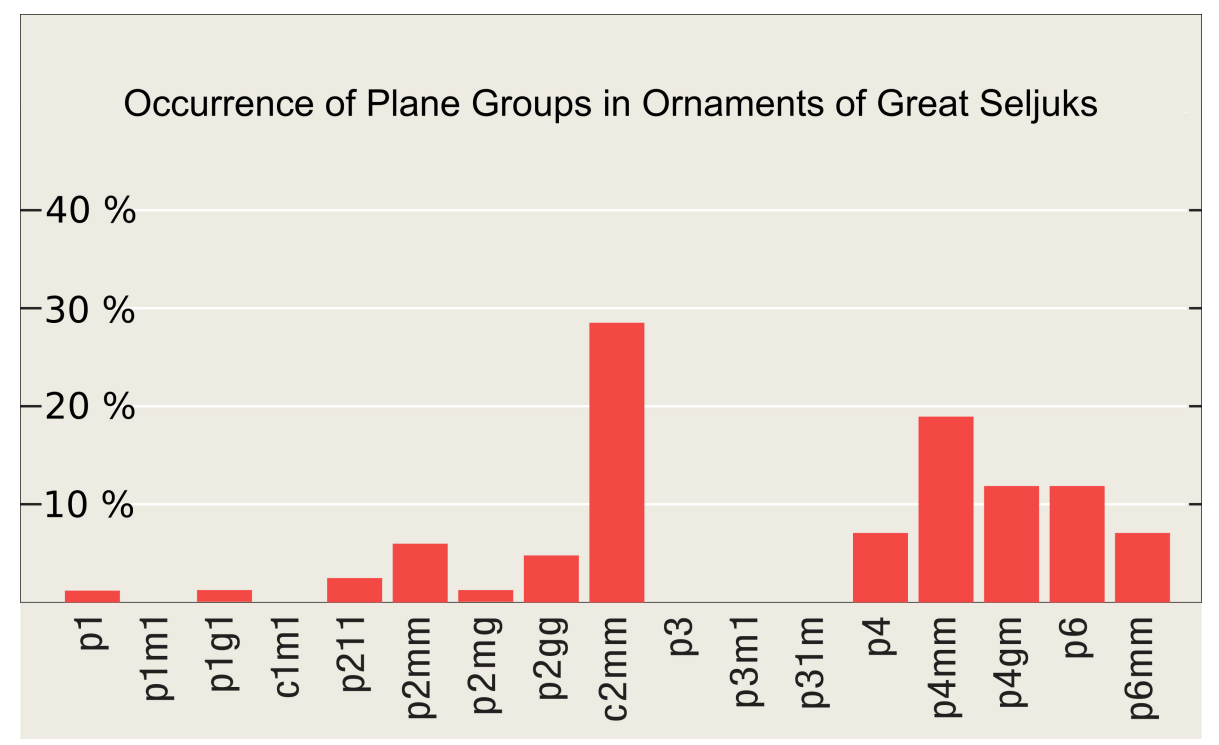

Figure 5: The plane symmetry groups of the ornaments of the Great Seljuk Empire mainly found in Iran. The classification is based on 84 individual objects.

\subsection{The Rum Seljuks}

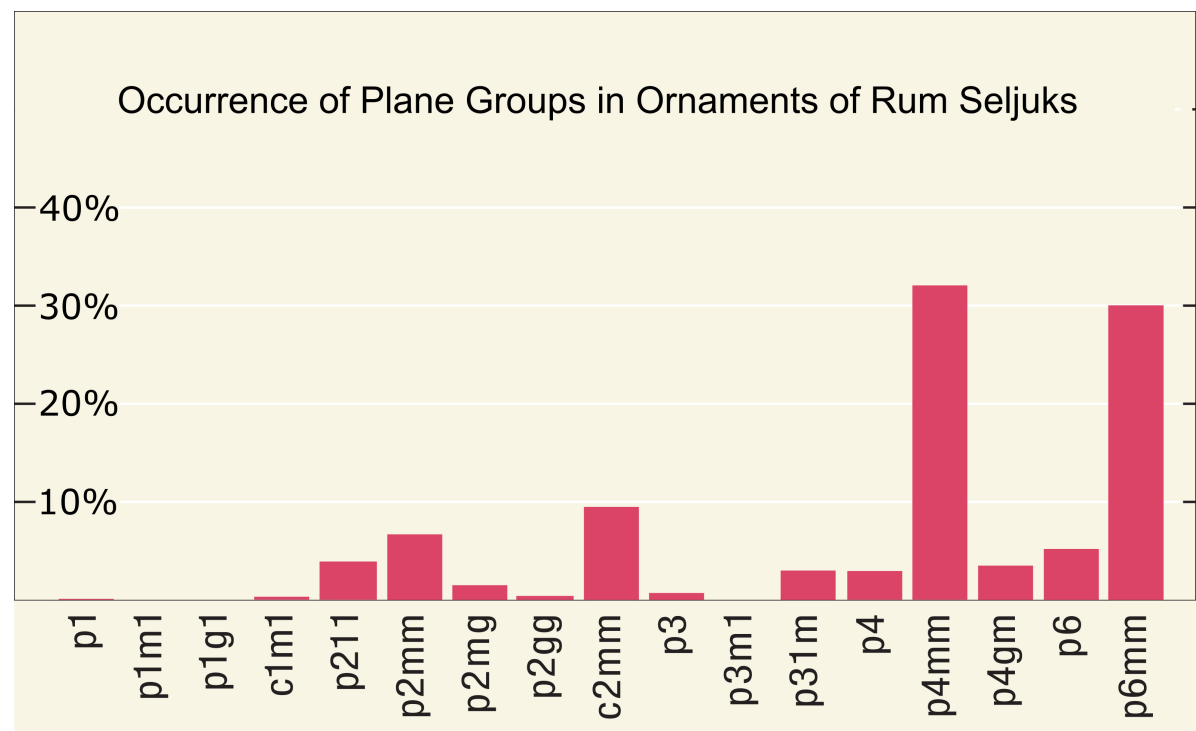

Figure 6: Classification of ornaments of the Sultanate of Rum Seljuks. The results are based on hand drawings by Gerd Schneider [12] and represent 1067 artifacts.

Seljuk warriors, mostly Turkmen tribes, infiltrated Anatolia after 1000. After the Battle at Manzikert in 1071 and the captivity of the Byzantine emperor a civil war broke out on Byzantine territory. The Turkic tribes took advantage of the unrest and founded their own sultanate, the Rum Seljuks. With the exception of the coastal regions in the west, they occupied most of Anatolia. Their first capital was Nicaea in the northwest; which was later conquered by the First Crusades in 1097. Konya became the next capital.

The Rum Seljuks have built great mosques, palaces, caravanserais, mausoleums, madrasas and shipyards. They existed until the impact of Mongol rule during the second half of the 13th century, when it was the Ilkhans, descendants of Genghis Khan, who took over their land. The best documentation about the Sultanate's work of art can be found in the monumental work of Gerd Schneider, which he created during his several years' stay in Istanbul [12]. Here I present in Figure 6 the results obtained from his meticulous hand drawings.

\section{Discussion}

\subsection{Visual inspection}

I first evaluate the results by visual inspection of the Figures 2-6. I find that almost all cultures prefer the fourfold symmetrical $p 4, p 4 m m$ or $p 4 \mathrm{gm}$. I can only speculate about the origin for this preference. In the case of ornaments carved on building materials, the reason could be the simple manufacture of each masonry block [17]. The reason could also lie in a religious practice, if the ornaments are found in a church, mosque, madrasa or monastery [16]. Threefold symmetry is quite rare in any repertoire. I note that both Arab Muslims and Rum Seljuks have predominantly used ornaments with double mirror reflections on sixfold, fourfold and twofold symmetries. The distribution of the 


\begin{tabular}{|c||c|c|c|c|c|}
\hline Groups & Armenia & Byzantium & M. Arabs & G. Seljuks & R. Seljuks \\
\hline \hline$p 1$ & 0.8 & 4.8 & 0.2 & 1.2 & 0.1 \\
\hline$p 1 m 1$ & 4.9 & 2.6 & 0.6 & 0 & 0 \\
\hline$p 1 g 1$ & 0 & 0.3 & 0.2 & 1.2 & 0 \\
\hline$c 1 m 1$ & 2.4 & 1.1 & 0.2 & 0 & 0.3 \\
\hline$p 211$ & 0 & 0.5 & 0.5 & 2.4 & 0.5 \\
\hline$p 2 m m$ & 5.7 & 3.7 & 6.6 & 6.0 & 6.7 \\
\hline$p 2 m g$ & 0.8 & 1.1 & 0.7 & 1.2 & 1.5 \\
\hline$p 2 g g$ & 0.8 & 0.1 & 0.2 & 4.8 & 0.4 \\
\hline$c 2 m m$ & 1.6 & 0.8 & 14.0 & 28.6 & 9.5 \\
\hline \hline$p 3$ & 0.8 & 0 & 0.4 & 0 & 0.7 \\
\hline$p 3 m 1$ & 0 & 0 & 0.4 & 0 & 0 \\
\hline$p 31 m$ & 2.4 & 0 & 1.4 & 0 & 3.0 \\
\hline \hline$p 4$ & 12.2 & 0.3 & 1.0 & 7.1 & 2.94 \\
\hline$p 4 m m$ & 54.5 & 78.5 & 31.4 & 19.0 & 32.1 \\
\hline$p 4 g m$ & 4.9 & 4.9 & 1.9 & 11.9 & 3.5 \\
\hline \hline$p 6$ & 1.6 & 1.2 & 4.9 & 11.9 & 5.2 \\
\hline$p 6 m m$ & 6.6 & 0 & 35.5 & 4.8 & 30.1 \\
\hline
\end{tabular}

Table 1: Occurrence of the individual symmetry groups (in percentage) in the artworks of Armenia, Byzantium, Muslim Arabs, Great Seljuks and Rum Seljuks. The rotational symmetries are grouped together.

plane groups looks remarkably similar, indicating an intensive interaction of cultures between Arab Muslims and Rum Seljuks.

Table 1 summarizes the occurrence of each symmetry group in five different cultures. We observe that ornaments with a rotational symmetry of 1 and 3 are rare overall. Threefold symmetrical ornaments are completely missing in Byzantium and the Great Seljuks. The fourfold symmetry is by far the most favorable in all groups. It is obvious that the interlacing in planar ornaments reduces the symmetry. The published results about the Arab-Muslim group neglect the interlacing [19]. To allow a comparison based on the same assumption, I have used the Armenian and Seljuk results after I have similarly neglected interlacing.

\subsection{Mathematical correlation}

In order to rigorously determine the efficiency of the interaction and the resulting correlation of the artwork between the five cultural groups considered here, I use a scientific approach. In the social sciences the Pearson correlation coefficient is used for metric variables [23]. To investigate overlapping elements of variables in natural sciences cosine similarity is sometimes preferred [24]. In physics and chemistry, overlap integrals are used [25].

I determine the correlation of the results considering the product of two vectors $X$ and $Y$ with 17 components $x_{i}$ and $y_{i}$ each represent the elements of the plane groups. This correlation function is a robust measure of the strength of pairwise interaction between two groups and quantifies the similarity between these cultural groups. I repeat the operation for all the members of the plane group:

$$
C=\frac{\vec{X}}{|X|} * \frac{\vec{Y}}{|Y|}=\frac{\sum_{i} x_{i} y_{i}}{\sqrt{\sum_{i} x_{i}^{2} \sum_{i} y_{i}^{2}}},
$$

while $i$ runs between 1 and 17, the number of plane groups. The sums over $x_{i}$ and $y_{i}$ are normalized to one. This metric is often used to assess the correlation of partially overlapping systems.

\begin{tabular}{|c||c|c|c|c|c|}
\hline$C$ & A & B & AM & GS & RS \\
\hline \hline A & 1 & 0.965 & 0.713 & 0.576 & 0.783 \\
\hline B & 0.965 & 1 & 0.636 & 0.512 & 0.705 \\
\hline AM & 0.713 & 0.636 & 1 & 0.646 & 0.988 \\
\hline GS & 0.576 & 0.512 & 0.646 & 1 & 0.649 \\
\hline RS & 0.783 & 0.705 & 0.988 & 0.649 & 1 \\
\hline
\end{tabular}

Table 2: Interaction factor $C$ between 1 and 0 , based on the occurrence of plane-group symmetries in the artwork from 5 medieval groups. A stands for Armenia, B for Byzantium, AM for Arab Muslims, GS for Great Seljuks and RS for Rum Seljuks.

To find the interaction $C$ in pairs between the two cultures, I use the above formula and obtain ten values for the correlation of Armenia, Byzantium, Arab Muslims, Great Seljuks and Rum Seljuks. The results are presented in Table 2. A high (low) value of $C$ near 1 (near 0 ) indicates a strong (weak) correlation, i.e., interaction, between the cultures $X$ and $Y$. There are several ways to interpret the values of $C$. The easiest way allows us to determine the strong interaction between certain two cultures. We see that the strongest interaction factor is between $0.96-0.99$ and is found for Armenia and Byzantium as well as for Muslim Arabs and Rum Seljuks. Similarly, I also add the correlation coefficients of each group with the other four groups and repeat this summation for all five groups. The sum obtained is a measure of the ability of the group to interact culturally or architecturally. A high value stands for a strong creativity of the group, while a lower correlation value $C$ is rather modest. The Great Seljuks were warriors and nomads. In their sultanate, the Persian people were responsible for civil 
affairs and administration. According to this analysis, the Great Seljuks were the least interacting group. I find that the groups that interact most with their neighbors are Rum Seljuks, Armenians and the Muslim Arabs.

\section{Conclusions}

The comparison of the frequent use of particular symmetries in ornaments of ethnic groups could be a useful indication of their interaction and mutual artistic influence. The similarity between two groups of the same religious belief is likely to lead to similar habits. In the present case, however, the Byzantine Empire and the Armenians are both Christians, but from different churches according to the Calcedonian Schism 451. Seljuks and the Umayyads or Abbasids are all Muslims, but with fundamentally different beliefs about the succession of the Prophet Mohammad. Therefore, religion gives us no indication of the artistic habits of the peoples concerned. Nor is the geography of their homeland similar; it differs from the mountainous regions of the Caucasus, the Seljuk prairies, to vast Arab desserts, and the coastal regions of the Byzantine Empire. What they have in common is their campaign through the region of cultural activity in the eastern part of present-day Turkey. Yet the exact occurrence of these cultures is geographically and chronologically limited. However, the activity of craftsmen was not limited by national borders. Even if there was a temporal shift in the occurrence of cultures, this fact only determines the direction of the flow of information.

I made several assumptions. Firstly, I have taken the symmetry properties of ornaments as a cultural indication of an ethnic group and neglected all other ornaments that have no symmetry. In order to quantify the symmetries unambiguously, I applied the crystallographic plane-group classification. I express the results as percentage frequencies of 17 plane groups each, which is a scientific way to evaluate the ornaments. I apply this method to five individual cultural groups that were neighbors at some time in the Middle Ages, namely the Armenians, the Byzantine Empire, the Muslim Arabs, the Great Seljuks and the Rum Seljuks.

In order to estimate the mutual interaction of these five groups, I have worked out an interaction coefficient $C$ for each ethnic group with the other four groups. This factor quantitatively describes the artistic similarities by calculating the overlapping of the frequency of the symmetries. The technique is common in many other areas of science; it is used in this context for the first time. Mathematically, a cultural group is a vector and its symmetry groups are the 17 components of the vector. The correlation factor is then the overlapping of the components for two cultural groups under consideration. I compare these values of each pair of groups to determine those two cultures that have influenced each other the most. Here is the strongest interaction between Byzantium and Armenia and between Muslim Arabs and Rum Seljuks. I also add up the $C$ values of each cultural group and find that the Rum Seljuks and Armenians have influenced their neighbors the most and vice versa.

The Byzantine Empire diffused into European territories after the siege of Constantinople by the Ottomans. It is conceivable that Byzantine craftsmen made a positive contribution to the flourishing Renaissance. The Great Seljuks disintegrated into smaller emirates under the influence of the Mongol invasion, while Rum Seljuks survived in Anatolia in the background for several centuries. The art of the Muslim Arabs reached its peak in various places, in Damascus with the Umayyads, in Baghdad among the Abbasids, and on the Iberian peninsula with the Umayyads of Andalusia. The Armenian civilization created artistic masterpieces in the Middle Ages and throughout history until today. They are the only group that has remained on their original Caucasian planes.

\section{Acknowledgements}

I would like to thank Prof. Dr. Alphan Sennaroğlu for his expert suggestions for the calculation of correlation functions and Fatma Erbudak for her support at every stage of this study. Both contributions have been very fruitful. This research has not funded by any agency.

\section{References}

[1] C. Brinton, J. B. Christopher, R. L. Wolff, A History of Civilization Vol. I, Prentice Hall, Englewood, NJ, 1960.

[2] D. K. Washburn, D. W. Crowe, Symmetries of Culture: Theory and Practice of Plane Pattern Analysis, University of Washington Press, Washington DC, 1991.

[3] D. Schattschneider, The plane symmetry groups: Their recognition and notation, Amer. Math. Monthly, 85(6) (1978), 439-450.

[4] L. Jones, Between Islam and Byzantium, Ashgate, Burlington, VT, 2007.

[5] J. J. Norwich, Byzantium, The Early Centuries, The Apogee, The Decline and Fall, Alfred A. Knopf, NY, 1997.

[6] A. E. Kaldellis, Romanland: Ethnicity and Empire in Byzantium, Harvard University Press, Cambridge, MA, 2019.

[7] M. Hattstein, P. Delius, Islam, Kunst und Architektur, Könemann, Köln, 2000.

[8] S. R. Canby, D. Beyazit, M. Rugiadi, A. C. S. Peacock, Court and Cosmos, The Great Age of the Seljuqs, The Metropolitan Museum of Art, NY, 2016.

[9] A. Hutt, L. Harrow, Iran 1, Scorpion Publications, London, 1977.

[10] A. Başan, The Great Seljuks: A History, Routledge, London, 2010.

[11] S. Mecit, The Rum Seljuqs: Evolution of a Dynasty, Routledge, London, 2014.

[12] G. Schneider, Geometrische Bauornamente der Seldschuken in Kleinasien, Dr. Ludwig Reichert, Wiesbaden, 1980.

[13] C. Hammond, The Basics of Crystallography and Diffraction, 4. Ed., Oxford Univ. Press, Oxford, 2015.

[14] G. Pólya, Über die analogie der kristallsymmetrie in der ebene, Z. Kristall., 60 (1924), 278-282.

[15] E. A. Müller, Gruppentheoretische und strukturanalytische Untersuchung der Maurischen Ornamente aus der Alhambra in Granada, Ph.D. Thesis, University of Zurich, 1944; El estudio ornamentos como applicatión de la teoría de los grupos de orden finito, Euclides (Madrid), 6 (1946), $42-52$.

[16] M. Erbudak, Symmetry analysis of the floor ornaments of the San Marco Cathedral in Venice, Heliyon, 5 (2019), e01320.

[17] M. Erbudak, A. Kyurkchyan, Armenian, Byzantine and Islamic Ornaments, Influences Among Neighbors, Kyurkchyan, Yerevan, 2019, doi.org/10.3929/ethz-b-000394011.

[18] A. Kyurkchyan (Author), H. H. Khatcherian (Photographer), Armenian Ornamental Art, Craftology, Yerevan, 2010.

[19] J. Bourgoin, Les Èlèments de L'Arabe, Librairie de Firmin-Didot, Paris, 1879; Arabic Geometrical Pattern and Design, Dover, New York, 1973.

[20] E. Makovicky, M. Malovicky, Arabic Geometrical Patterns - A Treasury for Crystallographic Teaching, Neues Jahrbuch für Mineralogie Monatshefte, 2 (1977), 58-68; S. J. Abas, A. S. Salman, Symmetries of Islamic Geometrical Patterns, World Scientific, Singapore, 1995.

[21] E. Makovicky, Symmetry, De Gruyter, Berlin, 2016.

[22] J. Bonner, Islamic Geometric Patterns, Springer, New York, 2017.

[23] Available at https://en.wikipedia.org:Pearson_correlation_coefficient.

[24] J. Ye, Cosine similarity measures for intuitionistic fuzzy sets and their applications, Math. Comput. Modelling, 53 (2011), 91-97.

[25] K. Rudenberg, K. O-Ohata, D. G. Wilson, Overlap integrals between atomic orbitals, J. Math. Phys., 7 (3) (1966), $539-546$. 